\title{
Opportunistic predation of fish by anomuran crabs (Crustacea, Anomura, Aeglidae) in rivers of southern Brazil
}

\author{
Marcoandre Savaris ${ }^{1,2}$, Silvana Lampert ${ }^{1}$, André Trevisan $^{1}$ \& Setuko Masunari ${ }^{1}$ \\ ${ }^{1}$ Departamento de Zoologia, Centro Politécnico, Universidade Federal do Paraná - UFPR, \\ Jardim das Américas, CP 19020, CEP 81531-980, Curitiba, PR, Brasil \\ ${ }^{2}$ Corresponding author: Marcoandre Savaris, e-mail: masavaris@yahoo.com.br
}

SAVARIS, M., LAMPERT, S., TREVISAN, A. \& MASUNARI, S. Opportunistic predation of fish by anomuran crabs (Crustacea, Anomura, Aeglidae) in rivers of southern Brazil. Biota Neotrop. 12(4): http:// www.biotaneotropica.org.br/v12n4/en/abstract?short-communication+bn01212042012

\begin{abstract}
The opportunistic predation on the fishes Astyanax fasciatus and Crenicichla sp. entangled in gill net by the aeglid crabs Aegla grisella and Aegla singularis was observed in rivers of southern Brazil. These events occurred in two rivers located at the National Forest of Passo Fundo, in Mato Castelhano municipality, Rio Grande do Sul State and Tangará municipality, Santa Catarina State. In both places the fish showed similar wound pattern, with eyes and fins being consumed first. However, predation of the whole body was also recorded, probably due to the high number of aeglid crabs feeding on the same individual. This record intended to contribute for understanding the natural diet of these crabs in freshwater environments.
\end{abstract}

Keywords: diet, fish, behavior, aeglid crabs.

SAVARIS, M., LAMPERT, S., TREVISAN, A. \& MASUNARI, S. Predação oportunista de peixes por eglídeos (Crustacea, Anomura, Aeglidae) em rios do Sul do Brasil. Biota Neotrop. 12(4): http://www.biotaneotropica. org.br/v12n4/pt/abstract?short-communication+bn01212042012

Resumo: A predação oportunista dos peixes Astyanax fasciatus e Crenicichla sp. emalhados em rede de espera pelos eglídeos Aegla grisella e Aegla singularis foi observada em rios do Sul do Brasil. Estes eventos ocorreram em dois rios na Floresta Nacional de Passo Fundo, município de Mato Castelhano, RS e no município de Tanguará, SC. Em ambos os locais os peixes apresentavam um padrão de mutilação semelhante, com olhos e nadadeiras sendo consumidos primeiramente. No entanto, a predação de todo o corpo também foi registrada, provavelmente em decorrência do elevado número de eglídeos se alimentando de um mesmo indivíduo. Esse registro visa contribuir para o entendimento da dieta natural dos eglídeos em ambientes de águas continentais.

Palavras-chave: dieta, peixes, comportamento, eglideos. 


\section{Introduction}

The family Aeglidae Dana, 1852 is the only anomuran crustacean that lives in continental waters. Its species are found in clear and well oxygenated waters of streams, rivers, lakes and stream caves; usually they are hidden under rocks and plant debris (Bond-Buckup \& Buckup 1994, Bond-Buckup 2003, Bond-Buckup et al. 2008, Dalosto \& Santos 2011).

According to the criteria of the International Union for Conservation of Nature (IUCN), from a total of 70 know species 23 are threatened, mainly due to their endemic distribution and to the visible degradation of freshwater environments. Therefore, these organisms should be a priority for ecological studies aiming the establishment of conservation measures (Bueno \& Bond-Buckup 2004).

The feeding habit has been investigated in the following aeglids: Aegla laevis laevis Latreille, 1818, Aegla perobae Hebling \& Rodrigues, 1977, Aegla platensis Schmitt, 1942, Aegla leptodactyla Buckup \& Rossi, 1977, Aegla camargoi Buckup \& Rossi, 1977, Aegla lingulata Bond-Buckup \& Buckup, 1994 and Aegla longirostri Bond-Buckup \& Buckup, 1994. They were characterized as opportunistic omnivorous, feeding on diversified food items such periphyton, organic matter coming from allochthonous plants, aquatic invertebrates, fish scales and fine particulate organic matter (Bahamonde \& López 1961, Burns 1972, Arenas 1978, Isler 1988, Magni \& Py-Daniel 1989, Lara \& Moreno 1995, Medina 1998, Bueno \& Bond-Buckup 2004, Castro-Souza \& Bond-Buckup 2004, Santos et al. 2008).

Studies based on stomach contents analysis, using more refined statistical methods have been only published recently. Castro-Souza \& Bond-Buckup (2004) evaluated the natural diet of $A$. camargoi and A. leptodactyla that occur in sympatry at Divisa River, in São José dos Ausentes municipality, Rio Grande do Sul State and Bueno $\&$ Bond-Buckup (2004) characterized the diet of A. plantensis and A. lingulata, from Arroio do Mineiro, southern Brazil. These four species have been considered opportunistic omnivorous, confirming the results of previous authors.

More recently, Santos et al. (2008) recorded plant tissues, organic material in advanced state of digestion, fragments of adults insects, aeglid body parts, clam shells, fish scales, and dipteran larvae in the stomach content of $A$. longirostri, from central region of Rio Grande do Sul State. On the other hand, aeglids constitute an important food item in the diet of the trouts Oncorhynchus mykiss (Walbaum, 1792) and Salmo trutta fario Linnaeus, 1758 (Burns 1972, Arenas 1978, Isler 1988, Lara \& Moreno 1995) and of the otter Lontra provocax (Thomas, 1908) (Medina 1998).

The present note is a record of an opportunistic predation on dead or dying fishes that were entangled in nets by two aeglid species in southern Brazil. The events occurred at a stream within the National Forest of Passo Fundo, in Mato Castelhano municipality, Rio Grande do Sul State (28 $18^{\prime} \mathrm{S}$ and $\left.52^{\circ} 10^{\prime} \mathrm{W}\right)$ in November 2008, and at Azul River, Peixe River Basin, Tangará municipality, Santa Catarina State $\left(27^{\circ} 06^{\prime} \mathrm{S}\right.$ and $\left.52^{\circ} 15^{\prime} \mathrm{W}\right)$ in May 2011.

\section{Materials and Methods}

The fishes were the target species and the aeglids belong to the by catch. These animals were captured with nets of $20 \mathrm{~m}$ length and aperture of $3 \mathrm{~cm}$ between opposite knots. These nets were set late in the afternoon and removed in the following morning; they remained about 12 hours in the water. The characid fish Astyanax fasciatus (Cuvier, 1819) and the cichlid Crenicichla sp. were captured in both sites, however, the aeglid Aegla grisella Bond-Buckup \& Buckup, 1994 was only recorded in Mato Castelhano, whereas Aegla singularis Ringuelet, 1948 only in Tangará.

Pictures of captured fishes were taken and, after that, they were fixed in $10 \%$ formalin, preserved in $70 \%$ alcohol and identified based on Zaniboni Filho et al. (2004) and Ribeiro et al. (2007), and the aeglids were fixed in $70 \%$ alcohol and identified according to Bond-Buckup \& Buckup (1994).

\section{Results and Discussion}

A total of 37 individuals of $A$. fasciatus, 14 of Crenicichla sp. and 21 eglids were obtained from two places. Eleven individuals (29.3\%) of $A$. fasciatus showed signs of carnivory by aeglids, while in Crenicichla sp. a total of five individuals (35.7\%) showed attack by these aeglids. During the net removal from the water only a few aeglids remained attached to it: most of them have loosen from the fishes and fell down back into the water (Figure 1). It is supposed
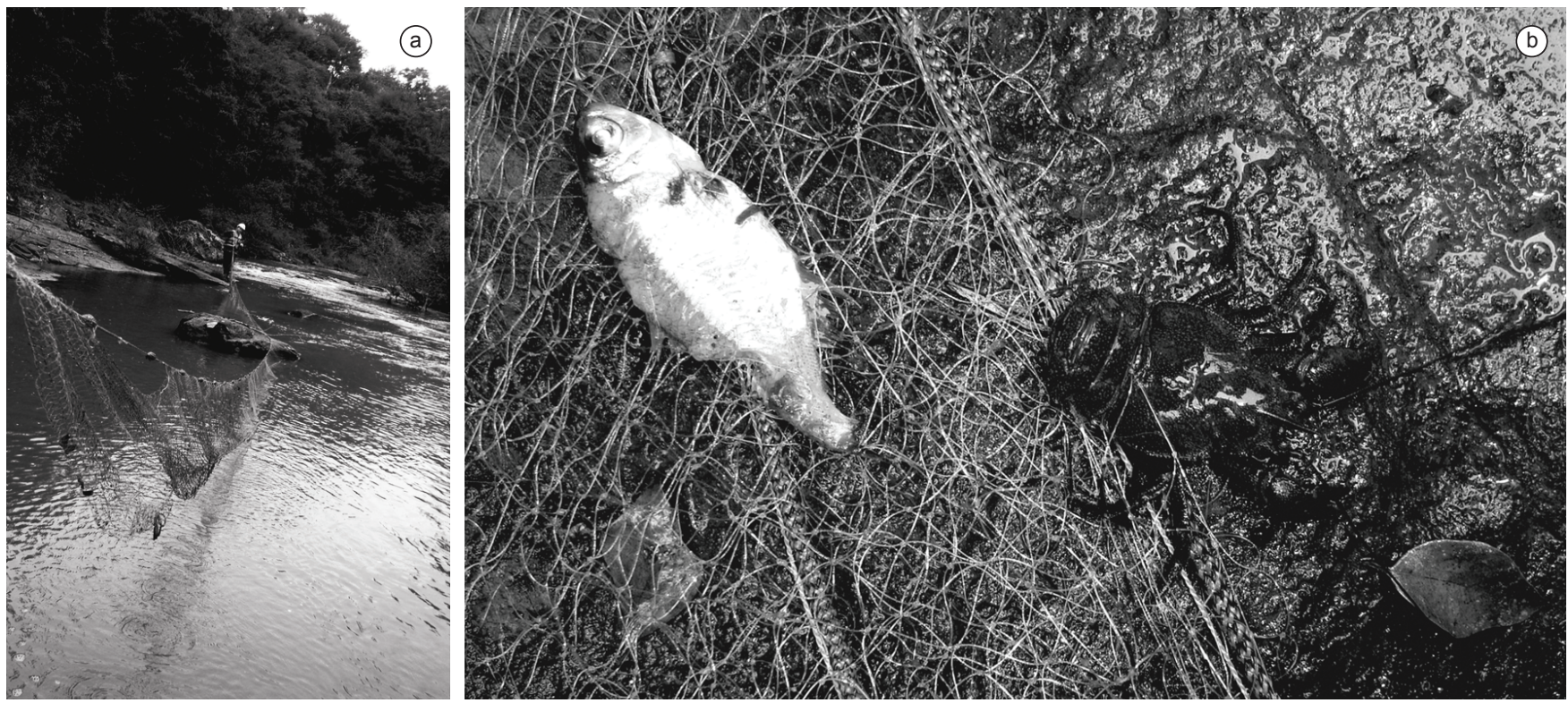

Figure 1. Fish and by catch capture. (a) Gill net pickup. (b) The fish Astyanax fasciatus and the aeglid Aegla singularis entangled in the gill net. Note that the fish suffered many bites. 
that aeglids were attracted to immobilized or dead fishes and were feeding on them.

The carnivory pattern was similar for both aeglids species, regardless of the prey species or sampling site. In all cases, aeglids firstly consumed the soft and protruding parts of the prey, like the eyes and fins (dorsal, caudal, anal, pelvic, and pectoral) (Figure 2ac). However, a total consumption of the fleshy parts of the fish was also recorded, probably a result of simultaneous attack by many aeglids (Figure $2 \mathrm{~d}$ ).

No record of fish body parts in the aeglid diet is available in the literature, certainly due to the difficulties in identifying them in the stomach content. However the presence of fish scales in it is clear evidence that aeglids can feed on fishes, as showed by Bueno
\& Bond-Buckup (2004) in 1.0\% of individuals of A. platensis from Mineiro Brook, in Taquara municipality. Curiously, this food item was absent in A. lingulata, a sympatric species of the former. In the same year, Castro-Souza \& Bond-Buckup (2004) also recorded fish scales in the sympatric species, A. camargoi (5.0\% of aeglids had this food item) and $A$. leptodactyla (1.2\%) from Divisa River, São José dos Ausentes municipality. Four year later, Santos et al. (2008) also found fish scales in $6.0 \%$ of individuals of $A$. longirostri from Itaara municipality. All record sites above mentioned are located in Rio Grande do Sul State. These data and the present communication indicate that fish could constitute an ordinary food item for all species of aeglid crabs.
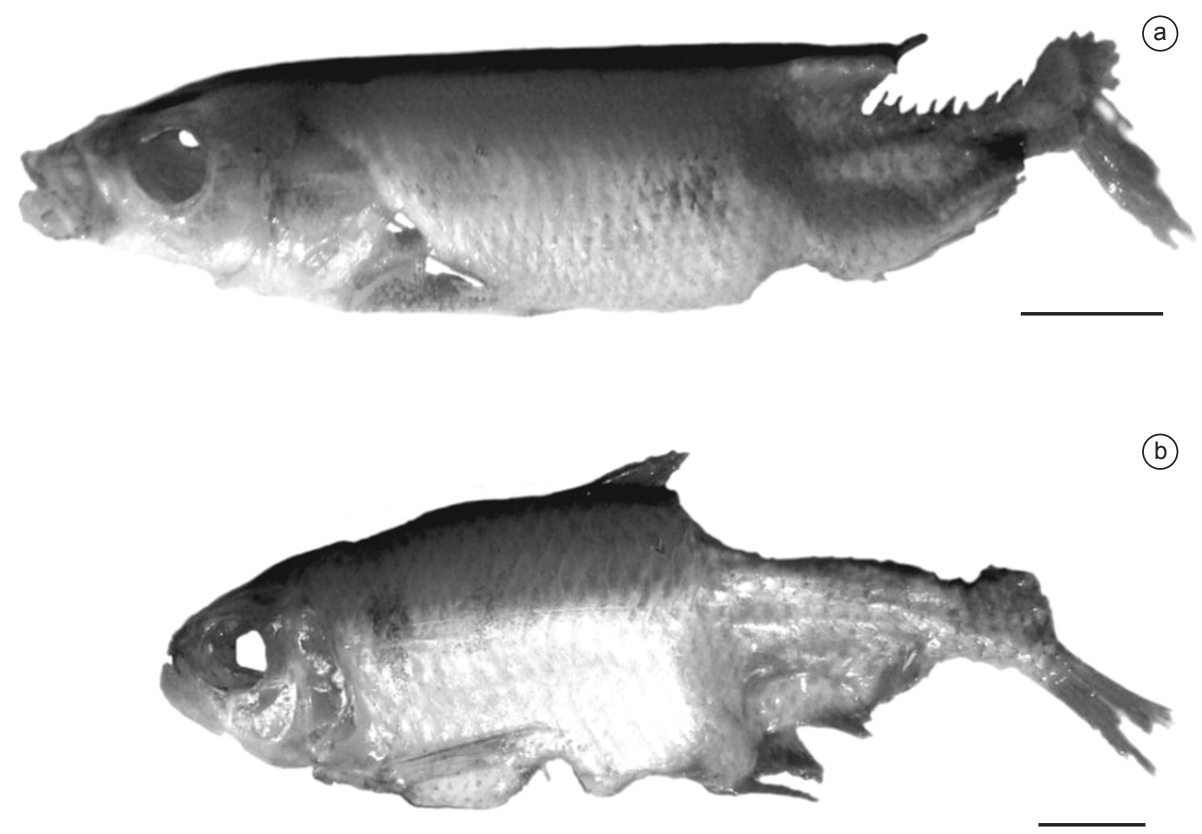

(b)
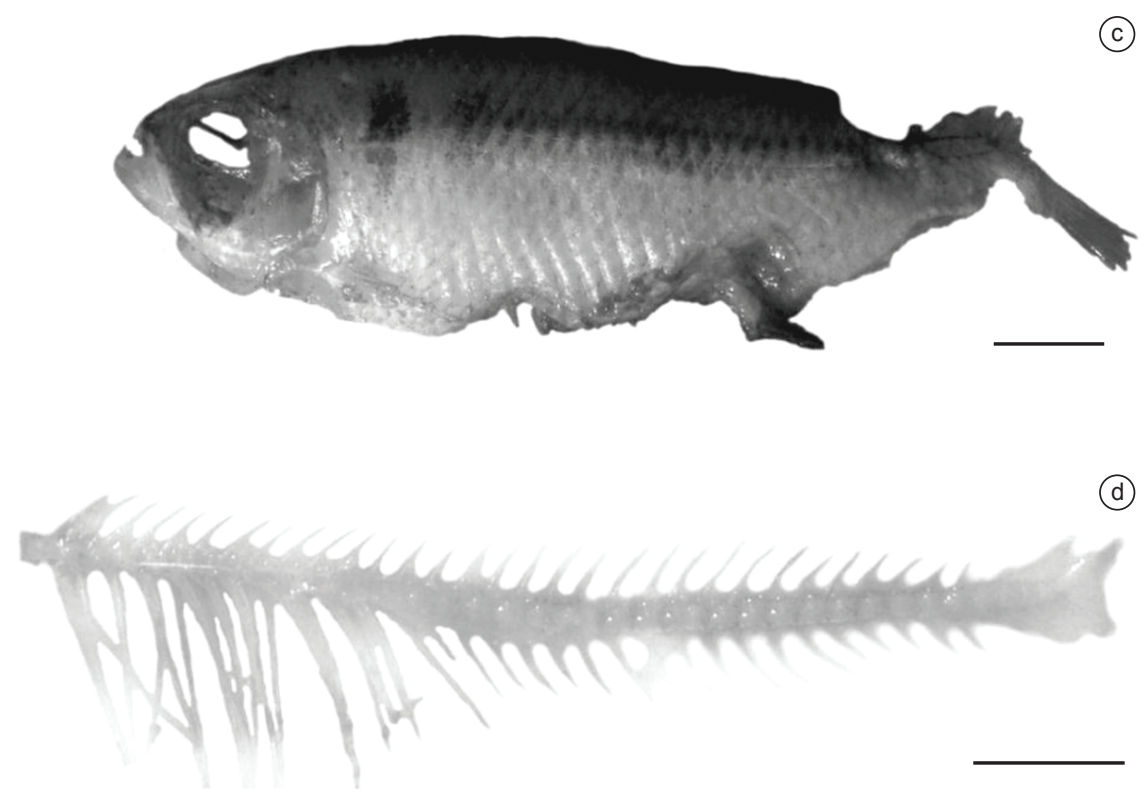

Figure 2. Fish that suffered carnivory by aeglids. (a) Crenicichla sp. (b and c) Astyanax fasciatus. (d) Fish skeleton. Scale $1 \mathrm{~cm}$. 
In this study, the aeglids behave as a perfect opportunistic predator, feeding on immobilized prey attached in a net, but it is possible to deduce that in the natural environments they are able to feed on dead fishes or on pieces of them that have left by other predators. Although the spectrum of food items of $A$. grisella and A. singularis is not yet known, it is clear that these aeglids can be carnivorous, which is actually the most efficient way of obtaining energy and proteins of high nutritional value.

\section{Acknowledgements}

We are grateful to Postgraduate Program on Zoology of Federal University of Paraná for facilities during the present work.

\section{References}

ARENAS, R.L. 1978. La cordillera de la costa como refugio de la fauna dulcícola preglacial. Archivos de Biología y Medicina Experimentales, Santiago, v.10, p.1-40.

BAHAMONDE, N. \& LÓPEZ, M.T. 1961. Estudios biológicos en la populación de Aegla laevis laevis (Latreille) de el Monte (Crustacea, Decapoda, Anomura). Invest. Zool. Chil. 7:19-58.

BOND-BUCKUP, G. 2003. Família Aeglidae. In Manual de identificação dos Crustacea Decapoda de água doce do Brasil (G.A.S. Melo, ed.). Loyola, São Paulo, p.21-116.

BOND-BUCKUP, G. \& BUCKUP, L. 1994. A família Aeglidae (Crustacea, Decapoda, Anomura). Arq. Zool. 2:159-346.

BOND-BUCKUP, G., JARA, C.J., PÉREZ-LOSADA, M., BUCKUP, L. \& CRANDALL, K.A. 2008. Global diversity of crabs (Aeglidae: Anomura: Decapoda) in freshwater. Hydrobiologia 595(1):267-273. http://dx.doi. org/10.1007/s10750-007-9022-4

BUENO, A.A.P. \& BOND-BUCKUP, G. 2004. Natural Diet of Aegla platensis and Aegla lingulata Bond-Buckup and Buckup (Crustacea, Decapoda, Aeglidae) from Brazil. Acta Limnol. Bras. 16(2):115-127.

BURNS, J.W. 1972. The distribution and life history of South American freshwater crabs (Aegla) and their role in trout streams and lakes. T. Am. Fish. Soc. 101(4):595-607. http://dx.doi.org/10.1577/1548 8659(1972) $101<595:$ TDALHO $>2.0 . \mathrm{CO} ; 2$
CASTRO-SOUZA, T. \& BOND-BUCKUP, G. 2004. The trophic niche of two sympatric Aegla Leach species (Crustacea, Aeglidae) in a tributary of hydrographic basin of Pelotas River, Rio Grande do Sul, Brazil. Rev. Bras. Zool. 21(4):805-813. http://dx.doi.org/10.1590/S010181752004000400014

DALOSTO, M. \& SANTOS, S. 2011. Differences in oxygen consumption and diel activity as adaptations related to microhabitat in Neotropical freshwater decapods (Crustacea). Comp. Biochem. Physiol. 160:461-466. PMid:21851859. http://dx.doi.org/10.1016/j.cbpa.2011.07.026

ISLER, M.L. 1988. Alimentación natural, conducta alimentaria y preferencia dietaria en Aegla denticulata Nicolet, 1849 (Crustacea: Decapoda: Anomura: Aeglidae). Unpublished Thesis, Universidad Austral de Chile, Chile.

INTERNATIONAL UNION FOR CONSERVATION OF NATURE - IUCN. IUCN Red List Categories (2001). Version 3.1 Prepared by the IUCN Species Survival Commission. IUCN, Gland, Switzerland and Cambridge.

LARA, G. \& MORENO, C. 1995. Effects of predation of Aegla abtao (Crustacea, Aeglidae) on the spatial distribution pattern and abundance of Diplodon chilensis (Bivalvia, Hyriidae) in Lake Panguipulli, Chile. Rev. Chil. Hist. Nat. 68:123-129.

MAGNI, S.T. \& PY-DANIEL, V. 1989. Aegla platensis Schmitt, 1942 (Decapoda, Anomura) um predador de imaturos de Simuliidae (Diptera, Culicomorpha). Rev. Saúde Públ. 23:258-259. http://dx.doi.org/10.1590/ S0034-89101989000300012

MEDINA, G. 1998. Seasonal variations and changes in the diet of southern river otter in different freshwater habitats in Chile. Acta Theriol. 43:285-292.

SANTOS, S., AYRES-PERES, L., CARDOSO, R.C.F. \& SOKOLOWICZ, C.C. 2008. Natural diet of the freshwater anomuran Aegla longirostri (Crustacea, Anomura, Aeglidae). J. Nat. Hist. 42(13-14):1027-1037. http://dx.doi.org/10.1080/00222930701882466

RIBEIRO, M.F., KÖHLER, A., DÜPONT, A. \& AZEVEDO, E.C.G. 2007. Os peixes do Rio Pardinho. Edunisc, Santa Cruz do Sul, 98p.

ZANIBONI-FILHO, E., MEURER, S., SHIBATTA, O.A. \& NUÑER, A.P.O. 2004. Catálogo de peixes ilustrado do alto Rio Uruguai. Ed. da UFSC, Tractebel Energia, Florianópolis, 128p. 